\title{
Az antihyperglykaemiás terápia deeszkalációja 2-es típusú diabetesben - amikor a kevesebb több
}

\author{
Jermendy György dr.
}

Bajcsy-Zsilinszky Kórház, Budapest

\begin{abstract}
A 2-es típusú diabetes - természetes kórlefolyásából adódóan - előrehaladó, progresszív jellegű, idült megbetegedés. Ezzel a ténnyel áll összefüggésben az, hogy az antihyperglykaemiás kezelés során a terápiában fokozatosan előre kell lépni a megkívánt glykaemiás kontroll biztosítása érdekében. A kezdeti életmód-terápia után rövidesen metformin indítandó, majd a monoterápia után kettős, olykor hármas kombinációs kezelés, végül injektábilis készítmény régebben kizárólag inzulin - adása válhat szükségessé. A szakmai irányelvek egybehangzóan hangsúlyozzák, hogy a kezelés intenzifikálása, eszkalációja, a kombinációs terápiák fokozatos, lépcsőzetes bevezetése alapvető szükségszerüség a betegek gondozása során. Az utóbbi években kiderült, hogy 2 -es típusú diabetesben helye van az antidiabetikus terápiában való visszafelé lépésnek, összetettebb kezelési formák helyett egyszerúbb terápiák választásának is. Ez a terápiás deeszkaláció, amely 2 -es típusú diabetesben az alábbi esetekben valósítható meg: 1) bariátriai sebészeti beavatkozások után; 2) bármi okból bekövetkező jelentős testsúlyvesztés kapcsán; 3 ) régebben teljes körű inzulinterápiára állított 2-es típusú betegek esetében, akiknél elmaradt az inzulinterápia indokoltságának revíziója; 4) fokozatosan kialakuló vesefunkció-romlás esetén; 5) előrehaladó magas életkorban, komorbiditások megjelenésekor; 6) a beteg szociális helyzetének romlásakor. A közlemény a 2-es típusú diabetesben olykor szükségessé váló terápiás deeszkalációval kapcsolatos irodalmi adatokat és a hazai szerény tapasztalatokat tekinti át.
\end{abstract}

Orv Hetil. 2019; 160(31): 1207-1215.

Kulcsszavak: 2-es típusú diabetes, antihyperglykaemiás kezelés, antidiabetikumok, glykaemiás kontroll, terápiás deeszkaláció

\section{De-escalation of antihyperglycemic treatment in patients with type 2 diabetes - when less is more}

Type 2 diabetes - due to its natural course - should be considered as a progressive chronic disease. Owing to this fact, antihyperglycemic treatment should be continuously increased stepwise in order to achieve proper glycemic control. Lifestyle modification should be initiated immediately after manifestation, shortly followed by metformin monotherapy, and later, dual or triple combinations and, finally, injectable derivatives - only insulin in the past - should be used for appropriate glycemic control. Guidelines about treatment approach of patients with type 2 diabetes unequivocally emphasize and describe in detail the need of treatment intensification, in other words, stepwise escalation in clinical practice. In the last couple of years, evidences provided that step down therapy, simplification of complex treatment regimens should also be considered in certain cases. This approach was generally called de-escalation in antihyperglycemic treatment which should be considered in patients with type 2 diabetes 1 ) after bariatric (metabolic) surgery; 2) with significant weight reduction irrespective of its origin; 3 ) with complex insulin regimens where re-evaluation of this treatment was missed; 4) with continuously decreasing renal function; 5 ) among elderly patients with comorbidities; 6 ) in social deprivation. In this article, data about therapeutic de-escalation of antihyperglycemic treatment in patients with type 2 diabetes and first experiences with this treatment approach are summarized.

Keywords: type 2 diabetes, antihyperglycemic treatment, antidiabetic drugs, glycemic control, de-escalation in therapy

Jermendy Gy. [De-escalation of antihyperglycemic treatment in patients with type 2 diabetes - when less is more]. Orv Hetil. 2019; 160(31): 1207-1215.

(Beérkezett: 2019. március 21.; elfogadva: 2019. április 1.)

A Szerkesztôség felkérésére készített tanulmány. 


\section{Rövidítések}

AACE $=$ (American Association of Clinical Endocrinologists $)$ Amerikai Klinikai Endokrinológusok Társasága; ACE $=($ American College of Endocrinology) Amerikai Endokrinológiai Kollégium; $\mathrm{ADA}=($ America Diabetes Association $)$ Amerikai Diabetes Társaság; $\mathrm{BMI}=($ body mass index $)$ testtömegindex; BOT $=$ (basal insulin supplemented oral treatment) bázisinzulinnal kiegészített orális kezelés; COPD $=($ chronic obstructive pulmonary disease) krónikus obstruktív tüdőbetegség; DPP4 = dipeptidil-peptidáz-4; EASD $=($ European Association for the Study of Diabetes) Európai Diabetes Társaság; eGFR = (estimated glomerular filtration rate) becsült glomerulusfiltrációs ráta; GADA = (glutamic acid decarboxylase antibody) glutaminsav-dekarboxiláz elleni antitest; GLPl $=$ (glucagon-like peptide-1) glükagonszerú peptid- $1 ; \mathrm{HbA}_{1 \mathrm{c}}=$ hemoglobin $\mathrm{A}_{1 \mathrm{c}}$; ICA $=$ (islet-cell antibodies) szigetsejtellenes antitestek; ICT $=$ (intensive conservative insulin treatment) intenzív konzervatív inzulinterápia; IGT = (impaired glucose tolerance) csökkent glükóztolerancia; LADA = (latent autoimmune diabetes in adults) lappangva kialakuló autoimmun diabetes felnőttkorban; MDI = (multiple daily insulin [injections] $)$ napi többszöri inzulinadás; SGLT2 $=$ (sodium-glucose co-transporter- 2$)$ nátrium-glükóz-kotranszporter-2; UKPDS $=($ United Kingdom Prospective Diabetes Study) az Egyesült Királyság prospektív diabeteses vizsgálata

A 2-es típusú diabetes természetes kórlefolyását a mérföldkőtanulmánynak tartott UKPDS (U. K. Prospective Diabetes Study) adatai már 1995-ben megvilágították [1]. Ekkor írták le először, hogy a 2-es típusú diabetes előrehaladó, progresszív jellegű, idült megbetegedés, miután a kórfejlődésben az inzulinrezisztencia mellett a hasnyálmirigy béta-sejtjeinek fokozatos funkcióromlása, az inzulinszekréció csökkenése áll. Az inzulinszekréciós kapacitás a 2-es típusú diabetes kórisméjének megállapításakor már kb. 50\%-ban elveszett, majd a további funkciókárosodás az aktuális terápiától függetlenül az évek során bekövetkezik. Bár ez az adat a diabetológiában szemléletformáló módon vált ismertté, későbbi megfigyelések árnyalták az első közlés eredményeit és következtetéseit. Már a UKPDS-munkacsoport közölte 1997-ben, hogy az újonnan felismert, 2-es típusú cukorbetegségben szenvedők bizonyos hányadában ICA(islet-cell antibodies) (életkortól függően 21\%-tól 4\%-ig terjedően) és GADA- (glutamic acid decarboxylase antibodies) pozitivitás (34\%-tól 7\%-ig terjedően) volt igazolható a betegség felismerésekor [2]. Ez felveti, hogy a UKPDS-kohorsz bizonyos százalékában (10\% körül) a klinikum alapján történő típusmeghatározás téves volt, s ez esetekben inkább LADA (latent autoimmune diabetes in adults) lehetett a helyes kórisme. Kétségkívül, az antitest-pozitivitással rendelkező betegek jelentős hányada (ICA-pozitivitás esetén 94\%, GADA-pozitivitás esetén 84\%) a követés hatodik événél már inzulinkezelésben részesült. Ez azt jelenti, hogy a UKPDS-kohorszban a betegek $\mathrm{kb}$. 10\%-ában a terápia viszonylag gyors eszkalációjára nem a 2 -es típusú diabetes gyors progressziója, hanem a téves típusmeghatározás miatt került sor. Marselli és mtsai donorhasnyálmirigyeket (2-es típusú diabetesben szenvedő versus [vs.] nem diabeteses egyének) vizsgálva, elektronmikroszkópos és immunkémiai módszereket alkalmazva arra a következtetésre jutottak, hogy 2-es típusú diabetesben a béta-sejt-tömegvesztés mértékéról vallott korábbi elképzelések túlzottnak minősíthetők [3]. Nemrégiben Ablquist és mtsai közel kilencezer skandináv beteg adatainak elemzésével kimutatták, hogy a felnőttkorban felismert diabeteses egyének több mint 60\%-a enyhe, elhízással kapcsolatos vagy életkorhoz kötött cukorbetegségben szenvedett, amire a gyors, progresszív lefolyás nem igazán volt jellemző [4].

A 2-es típusú diabetes előrehaladó jellegét - a progresszió mértékét és ütemét illetően nem teljesen egységes adatok és álláspontok ellenére - a szakmai közvélemény elfogadja. Ezzel a ténnyel áll összefüggésben a 2 -es típusú diabetes antihyperglykaemiás kezelésének egyik jellegzetessége: a terápiában fokozatosan előre kell lépni a megkívánt glykaemiás kontroll biztosítása érdekében. A kezdeti életmód-terápia után rövidesen metformin indítandó, majd gyógyszeres monoterápia után kettős, olykor hármas kombinációs kezelés, végül injektábilis készítmény - régebben kizárólag inzulin, ma inkább GLPl-receptor-agonista készítmény vagy a kettő fix kombinációja is - alkalmazható. A gyógyszeres terápia megválasztásakor a lépcsőzetes, előrehaladó kezelési elv alkalmazása, a terápia intenzifikálása, eszkalációja, a kombinációs terápiák fokozatos, egymás utáni bevezetése alapvető szükségszerúség a betegek évekre elnyúló gondozása során. Ezt az elvet a korábbi és jelenlegi nemzetközi szakmai állásfoglalások, ajánlások (AACE-ACE 2017, 2018, ADA-EASD 2015, 2018) egyirányú, előre mutató nyíllal jelezték a terápiás algoritmusábrákon [5-8].

Az utóbbi években - nem teljesen függetlenül a bariátriai sebészet térhódításától és az új innovatív készítmények elterjedésétől - kiderült, hogy 2-es típusú diabetesben adott esetben helye van az antidiabetikus terápiában való visszafelé lépésnek, összetettebb kezelési formák helyett egyszerúbb terápiák választásának, a terápiás deeszkalációnak is. Az elméleti háttér megalapozott, a klinikai tapasztalatok fokozatosan gyưltek, így nyilvánvalóvá vált, hogy adott esetben lehetőség van a terápia egyszerúsítésére, a teljes inzulinterápia elhagyására, az orális szerek többes kombinációja helyett egyszerúbb kezelési gyakorlat folytatására.

A terápiás deeszkaláció fogalma számos szakterületen használatos. Onkológiában a tumorellenes összetett kezelés [9], kardiológiában a kombinált thrombocytaaggregáció-gátló terápia [10], pulmonológiában az idült obstruktív tüdőbetegség (COPD) többes kezelése kapcsán [11], gasztroenterológiában a gyulladásos bélbetegségekkel összefüggésben [12], infektológiában az antimikrobás kezeléssel kapcsolatban [13] már felmerült, hogy a beteg javát olykor az összetett kezelés egyszerúsítése, a terápiában való visszalépés szolgálhatja. A diabe- 
tológiai irodalomban a terápiás deeszkaláció viszonylag új keletû fogalom [14], ezért érdeklődésre tarthat számot a jelenlegi ismeretek összefoglalása.

\section{Nevezéktan}

Az összetett antidiabetikus terápiában való visszafelé lépést jelző tevékenység elnevezése nem egységes, nevezéktana most kezd kialakulni. Az előrelépés a terápia intenzifikálását, eszkalációját jelenti, az ellenirányú tevékenységre kell megfelelő elnevezést találni. Az intenzifikálás megnevezés kezdetben, mintegy két évtizeddel ezelőtt, meglehetős ellenérzés közepette került be a diabetológiai gyakorlatba, de - jobb híján - mára már megszoktuk, és elfogadottá vált, noha a nyelvtudománnyal foglalkozók bizonyára berzenkednek a kifejezés hallatán. Miután az intenzifikálás kifejezést is csak nagy nehezen szoktuk meg, a deintenzifikálás megnevezés elterjedését nem lenne célszerű szorgalmazni. Az angol nyelvű szakirodalomban több kifejezés található (simplification, deprescribing, deintensification, step down therapy), úgy látszik, hogy az összetett, több készítményt tartalmazó terápiáról az egyszerúbb, kevesebb készítményt tartalmazó terápiára való visszatérés/átállás megnevezésére a diabetológiai irodalomban talán a deeszkaláció (de-escalation) megnevezés használatos a leggyakrabban.

\section{Mikor kell mérlegelni az antihyperglykaemiás terápia deeszkalációját 2-es típusú diabetesben?}

A 2-es típusú diabetesben megvalósítható terápiás deeszkalációval kapcsolatos irodalom meglehetősen szegényes. Gyakorlati tapasztalatokat is tekintve az alábbi esetekben jön szóba a deeszkaláció: 1) bariátriai sebészeti beavatkozások után; 2) bármi okból bekövetkező jelentős testsúlyvesztés kapcsán; 3) régebben teljes körü inzulinterápiára állított 2 -es típusú betegek esetében, akiknél elmaradt az inzulinterápia indokoltságának revíziója; 4) fokozatosan kialakuló vesefunkció-romlás esetén; 5 ) előrehaladó magas életkorban, komorbiditások megjelenésekor; 6) a szociális helyzet romlásakor (1. táblázat). A terápiás deeszkaláció mérlegelése, kivitelezése a cukorbetegek kezelésében kellő jártassággal rendelkező szakember irányításával valósulhat meg, ezért a napi gyakorlatban érdemes belgyógyász-diabetológus véleményét kikérni akkor, ha az ilyen jellegú terápiamódosításnak a szükségessége felmerül.

\section{Bariátriai (metabolikus) sebészeti beavatkozás után}

A bariátriai (metabolikus) sebészeti beavatkozások fokozatosan terjedtek el a gyakorlatban, azok hazánkban is elérhetők. A szakmai kérdések sebészeti, belgyógyászati,
1. táblázat $\mid$ Klinikai körülmények, amikor 2-es típusú diabetesben a terápiás deeszkaláció lehetőségét indokolt mérlegelni

1. Bariátriai (metabolikus) sebészeti beavatkozás után

2. Bármely okból bekövetkező jelentős testsúlyvesztés során

3. Komplex inzulinterápiában részesülő betegek körében - évek óta folytatott változatlan kezeléssel, amelynek indokoltsága kétséges,

- újonnan, indokoltan megkezdett kezeléssel, de a terápia folytatásának újraértékelése elmaradt,

- szülést követően, ha a várandósság alatt vagy pregesztációs gondozás során inzulinterápia kezdésére volt szükség,

- sebészeti beavatkozás, interkurrens betegség után, amikor az átmenetileg indokolt napi többszöri inzulinadás további szükségességének megítélése elmaradt

4. A renalis funkció romlásakor

5. Előrehaladó életkor, komorbiditások megjelenése esetén

6. A beteg szociális helyzetének romlásakor

pszichiátriai és pszichológiai vonatkozásait, az indikáció gondos mérlegelésének és az utógondozásnak a jelentőségét hazai [15-18] és nemzetközi közlemények [1925] már évek óta tárgyalják. Az elhízásban szenvedő 2 -es típusú cukorbetegek kezelési ajánlásai között a bariátriai sebészeti lehetőséget külön nevesíti a 2018-ban megjelent ADA-EASD konszenzusriport [8], de a hazai diabetológiai szakmai irányelvben is (2017) önálló fejezet foglalkozik ezzel a kérdéskörrel [26].

Az ADA-EASD legutóbbi, 2018-ban publikált konszenzusriportja [8] ajánlásként fogalmazza meg, hogy a bariátriai (metabolikus) sebészeti eljárások mérlegelése ajánlott olyan felnőttkorú, 2-es típusú diabetesben szenvedő betegek körében, akiknek BMI-értéke $\geq 40,0$ $\mathrm{kg} / \mathrm{m}^{2}$, vagy BMI-értékük 35,0-39,9 kg/m² közötti, de a kitartóan folytatott testsúlycsökkentő, nem sebészeti próbálkozások nem voltak sikeresek, és azok nem eredményezték a társuló betegségek javulását sem. Ázsiai eredetű betegekben a határértékek valamelyest alacsonyabbak. A metabolikus sebészeti beavatkozások jelentősen javítják a glükózkontrollt, sőt a diabetes remisszióját is eredményezhetik. A remisszió olykor évekig is eltarthat. Értelemszerűen, a glükózkontroll javulása szükségtelenné teszi a korábbi, általában kombinált antihyperglykaemiás kezelés fenntartását, azaz a terápia deeszkalációjára van szükség, röviddel a mútéti beavatkozás után, elkerülendő a hypoglykaemia kialakulását. Érdekes, hogy a hyperglykaemia jelentős javulása már a testsúlyvesztés előtt, röviddel a mútét után megfigyelhető; ennek a jelenségnek a magyarázataként a bélrendszerben termelődő inkretin hormonok fokozott elválasztását jelölik meg. Jellemző, hogy a betegek többségében az antihyperglykaemiás gyógyszeres kezelést teljesen el lehet hagyni, de több évre terjedő követés tanulsága szerint később az antidiabetikus kezelés újrakezdésére szükség lehet a betegek egy részében [24]. Mindebból adódik, hogy a sebészeti testsúlycsökkentő terápiát és az utógondozást 
végző szakembercsoportban belgyógyásznak, diabetológusnak is elérhetőnek kell lennie.

A hazai, 2017-ben publikált szakmai irányelv [26] ajánlása szerint a testsúlyfelesleggel rendelkező 2-es típusú cukorbetegek körében a súlycsökkentő kezelés első lépése az intenzív életmódkezelés: 6 hónapon belül 5\%os súlycsökkenés előirányzása célszerü minden olyan túlsúlyos, 2-es típusú diabetesben szenvedő betegnek, aki kész a súlyleadásban együttmúködni. Bariátriai sebészeti beavatkozás jöhet szóba, ha a BMI $>35,0 \mathrm{~kg} / \mathrm{m}^{2}$, $\mathrm{s}$ ha az életmódkezelés, valamint a kiegészítő gyógyszeres terápia a súlyleadás tekintetében érdemben eredménytelen maradt. A beavatkozásból a legtöbbet a $\mathrm{BMI}>40,0 \mathrm{~kg} / \mathrm{m}^{2}$ értékkel rendelkezők profitálnak, de a beavatkozás szóba jön a BMI>35,0 kg/m² értékkel rendelkezők körében is. A glykaemiás kontroll jelentős javulása a korábbi antidiabetikus kezelés leépítését, deeszkalációját teszi szükségessé. A diabetes remissziójával összefüggésben a microvascularis szövődmények kialakulásának kockázata is csökken [25]. A diabetes remiszsziójának esélyét növeli a fiatalabb életkor, a rövidebb betegségtartam, a jobb anyagcserehelyzet és az inzulin nélküli antidiabetikus kezelés.

A bariátriai sebészeti beavatkozásnak jól ismert módon kockázata van, ezért helyes, ha ezekre a beavatkozásokra nagy tapasztalattal rendelkező, kiemelt centrumokban kerül sor, ahol a társszakmák képviselői is rendelkezésre állnak. Erre már csak azért is szükség van, mert az utógondozás során belgyógyászati, endokrinológiai, pszichiátriai, dietetikai és diabetológiai vonatkozású gondok merülhetnek fel. Érdekes kérdés, hogy sikeres mütét, a 2-es típusú diabetes remissziója után milyen antihyperglykaemiás kezelés indítandó abban az esetben, ha évek során a mégis kiújuló diabetes a gyógyszeres antihyperglykaemiás kezelés újrakezdését teszi szükségessé. Erről jelenleg csak egyedi tapasztalatok állnak rendelkezésre, szakmai irányelv nem taglalja ezt a kérdést [27].

\section{Bármely okból bekövetkezó jelentôs testsúlyvesztés kapcsán}

A 2-es típusú diabetesben szenvedő, testsúlyfelesleggel rendelkező felnőtt betegek körében az életmód-terápia (orvosi táplálkozásterápia, fokozott fizikai aktivitás) megfelelő együttmúködés esetén - eredményre vezethet, a testsúly csökken, a glykaemiás kontroll javul, a korábbi antihyperglykaemiás kezelést módosítani lehet, a terápia deeszkalációjára kerül sor. Legújabban a 2-es típusú diabetes teljes remissziójáról közöltek adatokat alapellátási szinten megvalósított életmódbeli intervenció eredményeképpen [28]. Az Egyesült Királyságban végzett DiRECT-vizsgálatban az antidiabetikus és antihipertenzív szereket is elhagyták, a kétéves eredmények szerint a bevont betegek egyharmada a testsúlyvesztéssel összefüggésben teljes remisszióban volt [29]. Nagy kérdés, hogy a tanulmányban szereplő intervenció mennyiben ültethető át a mindennapi gyakorlatba.
Érdemes áttekinteni, hogy az elhízás kezelésére rendelkezésre álló hazai készítményekkel kapcsolatban megfigyelhető-e a glykaemiás kontroll olyan mértékü javulása, amely az antihyperglykaemiás kezelésben való visszalépés, deeszkaláció megvalósítását lehetővé tenné. Európában az elhízás kezelésére regisztrált, hazánkban még nem használatos a GLPl-receptor-agonista liraglutid 3,0 mg/nap dózisú kiszerelése $\left(\right.$ Saxenda $\left.^{\circledR}\right)$, amelynek hatékonyságát és biztonságosságát 2-es típusú cukorbetegek körében a SCALE-Diabetes vizsgálatban tesztelték [30]. Az 56 hétig tartó, kettős vak-, placebokontrollált, randomizált vizsgálatban a testsúlycsökkenés mindhárom elsődleges végpontja teljesült. Az antidiabetikus kezelést a betegek nagyobb arányában lehetett redukálni liraglutid (vs. placebo) mellett. A centrális támadáspontú naltrexon/bupropion kombináció (Mysimba ${ }^{\circledR}$ ) az utóbbi években vált hazánkban is elérhetővé az elhízás kezelésére [31]. A COR-Diabetes vizsgálatban a készítmény hatékonyságát és biztonságosságát tesztelték elhízott, 2 -es típusú diabetesben szenvedők körében [32]. Az 56 hétig tartó, placebokontrollált, kettős vak-, randomizált vizsgálatban a testsúlycsökkenés elsődleges végpontja teljesült, a $\mathrm{HbA}_{\mathrm{lc}}$-érték értékelhetően jobban csökkent naltrexon/bupropion (vs. placebo) mellett. Bár az aktív ágon a glykaemiás kontroll jobban javult, mint a placeboágon, az antidiabetikumok száma nem volt csökkenthető. Ebben a vonatkozásban annyi volt megfigyelhető, hogy a szükségessé váló antidiabetikumkiegészítésre vagy -dózisnövelésre ritkábban került sor naltrexon/ bupropion (vs. placebo) mellett $(22,3 \%$ vs. $35,2 \%$; $\mathrm{p}<0,01)$. Az orlistat $\left(\right.$ Xenical $\left.^{\circledR}\right)$ gastrointestinalis lipázinhibitorként fejti ki hatását. A XENDOS-vizsgálatban igazolták, hogy testsúlycsökkentés mellett a 2-es típusú diabetes kialakulásának kockázatát mérsékli, ez azonban csak IGT (csökkent glükóztolerancia) stádiumában lévő elhízott egyének körében volt statisztikailag igazolható [33]. A készítmény a jellegzetes mellékhatása miatt kevésbé használatos; nincs adat arra nézve, hogy 2-es típusú diabetesben alkalmazva módosítható-e az antidiabetikus kezelés.

Összefoglalva: az életmód-terápia - megfelelő körülmények esetén akár háziorvosi szinten bevezetett intervenció eredményeképpen is - a 2-es típusú diabetes remisszióját, az antidiabetikus kezelés teljes elhagyását eredményezheti az érintett betegek egy részében. A hazánkban jelenleg regisztrált/elérhető, elhízás elleni gyógyszerek közül egyedül a liraglutid nagyobb dózisa (3,0 mg/nap) mellett kell az antihyperglykaemiás kezelés deeszkalációját mérlegelni.

\section{Komplex inzulinterápiában részesülő betegek körében}

A 2-es típusú diabetes kezelésében a terápia intenzifikálásának szüksége végül inzulinterápia bevezetését indokolhatja. A nem inzulinszerű injektábilis készítmények (GLPl-receptor-agonisták) megjelenése előtt hosszú 
éveken keresztül az volt a gyakorlat, hogy az orális szerek után először általában bázisinzulin adása következett (BOT: bázisinzulinnal kiegészített orális kezelés [basal insulin supplemented oral treatment]), amely később prandialis inzulinok hozzáadásával teljes inzulinkezeléssé egészült ki. Arra alkalmas betegeknél megvalósítható volt az intenzív konzervatív inzulinterápia (ICT: intensive conservative insulin treatment), a felnőtt betegek körében a gyakorlatban ez sok esetben csak napi többszöri inzulinadást (MDI: multiple daily insulin [injections]) jelentett ( \pm megtartott orális szerek). Megfigyelhettük ezeknél a betegeknél, hogy inzulinterápia mellett a testsúlyuk évek alatt elég jelentősen gyarapodott, a glykaemiás kontroll általában kívánnivalót hagyott maga után, és a hypoglykaemia kockázata sem volt elhanyagolható. Összességében véve az akkori lehetőségek mellett a komplex inzulinterápián belül az ICT vagy az MDI választása - más készítmények hiányában - inkább kényszerü, semmint optimális lépés volt. Az új, innovatív készítmények, elsősorban a GLPl-receptor-agonisták megjelenése azonban lehetővé teszi, hogy az előzőekben körvonalazott betegeknél átértékeljük a korábbi komplex inzulinterápia ( \pm orális szerek) fenntartásának szükségességét.

Ha az ICT-vel vagy MDI-vel kezelt 2-es típusú cukorbetegek $\mathrm{HbA}_{\mathrm{lc}}$-értéke az egyéni célérték felett van, akkor nyilvánvaló, hogy a terápián változtatni indokolt. Sajnos előfordul, hogy ez nem történik meg, az adott inzulinterápia szükségességének megítélése elmarad, s a legegyszerúbb megoldásként az inzulindózisok emelésére kerül sor. Ez azonban hosszú távon nem előnyös, mert további testsúlygyarapodást indukál, aminek következtében a glykaemiás kontroll egy idő után ismét romlik, így a beteg kezelése rossz irányú, felfelé haladó spirálba kerül. A mai lehetőségek rendelkezésre állásával indokolt, hogy ezeknek a betegeknek az inzulinterápiáját áttekintsük, s éljünk a deeszkaláció lehetőségével. Ennek során a metformin-alapterápiát - ha a beteg tolerálja a készítményt - célszerü megtartani, inzulin helyett napi egyszeri GLPl-receptor-agonistát, szükség esetén SGLT2-gátló későbbi hozzáadásával lehet megpróbálni, általában sikerrel. A korábbi szulfonilureát - ha volt - általában el lehet hagyni. Választani lehet GLPl-receptoragonista + bázisinzulin-analóg fix kombinációt (liraglutid + degludek vagy lixiszenatid + glargin) is. Ha a feltételek adottak, akkor a terápiás deeszkaláció sikeres lesz, a glykaemiás kontroll javul, a beteg testsúlya, a hypoglykaemia kockázata, a szúrások száma csökken, ami összességében véve az életminőség javulását eredményezi. Fontos körülmény azonban, hogy ha az inzulint végleg el kívánjuk hagyni, vagy SGLT2-gátló készítményt akarunk beépíteni, célszerü meggyőződni arról, hogy a korábban inzulinnal kezelt beteg ténylegesen 2-es típusú diabetesben szenved-e, és van-e elegendő inzulinszekréciója. A klinikum mellett a C-peptid (és szigetsejtellenes autoantitestek) meghatározása lehet a segítségünkre [34, 35]. Nyilvánvaló ugyanis, hogy ha a beteg diabetesének típusmeghatározásában tévedünk (nem 2-es típusú diabetesról van szó), vagy az adott 2-es típusú cukorbetegnek a hosszú betegségtartammal öszszefüggésben már nincs elegendő inzulinszekréciója, akkor az inzulin elhagyásával a helyzetet nem javítjuk, hanem ronthatjuk - ami nyilvánvalóan nem lehet cél. Elkerülendő azonban az is, hogy téves típusmeghatározás folytán 1-es típusú diabetesben szenvedőnek ajánljunk olyan készítményt, amelyet csak 2-es típusú diabetes kezelésére regisztráltak.

Hazai vizsgálati eredmény is rendelkezésre áll arról, hogy korábban MDI-vel kezelt, jó glykaemiás kontrollú, 2-es típusú diabetesben szenvedő cukorbetegek körében is érdemes a terápiás deeszkaláció lehetőségével élni, mert az több szempontból előnyös lehet a beteg számára. Taybani és mtsai kongresszuson bemutatott klinikai vizsgálatának előzetes eredményei szerint a bevont 48 beteg (életkor 65,0 $\pm 8,6$ év, testsúly 90,25 $\pm 18,83 \mathrm{~kg}$, BMI $32,28 \pm 6,77 \mathrm{~kg} / \mathrm{m}^{2}$, diabetestartam $12,3 \pm 8,1$ év, $\mathrm{HbA}_{\mathrm{lc}}$ 6,48 $\pm 0,65 \%$, teljes inzulindózis 40,9 $\pm 11,1$ $\mathrm{E} /$ nap \pm metformin) esetében a korábbi napi többszöri inzulinadás helyett alkalmazott napi egyszeri liraglutid + degludek fix kombináció ( \pm metformin) a követés $(96$ nap) során javította a $\mathrm{HbA}_{\mathrm{lc}}$-értéket, csökkentette a testsúlyt, a BMI értékét és a hypoglykaemia előfordulását. Összességében véve a betegek életminősége is javult a terápia egyszerüsítése révén [36].

Az újonnan felismert, 2-es típusú diabetesben szenvedők antihyperglykaemiás kezelése inzulinnal indul akkor, ha a manifesztáció kapcsán klasszikus klinikai panaszok és tünetek, illetve katabolikus állapot jelei észlelhetők, magas (általában $10,0 \%$ feletti) $\mathrm{HbA}_{\mathrm{lc}}$-érték és jelentősen emelkedett vércukor (éhomi >13,9, random >16,7 mmol/l) kíséretében [26]. A megfelelő inzulinkezelés ilyenkor általában humán inzulinnal folytatott ICT szokott lenni, napi négy szúrással. A glükóztoxicitás áttörése után, megfelelő életmód-terápia mellett a legtöbbször látványosan javul a glykaemiás kontroll, és csökken a beteg testsúlya is. Néhány hónapos inzulinterápia után mérlegelendő, hogy át lehet-e térni egyszerübb kezelési formára. A betegek jelentős hányadában megvalósítható a terápiás deeszkaláció, amelynek sikerét elősegíti, ha a betegnek van saját inzulintermelése (amiről a C-peptid értékének meghatározásával tájékozódni tudunk), a testsúlya ténylegesen csökken, és az inzulinigénye nem nagy. Általában sikeresek lehetünk ilyen esetekben a megtartott metformin mellett alkalmazott GLPl-receptor-agonista vagy GLPl-receptor-agonista + bázisinzulin-analóg fix kombináció választásával, de olykor csak orális kezelési rendszer (például metformin + SGLT2-gátló, esetleg hármas orális kombináció) is eredményes lehet. Ilyen esetekben a jó glykaemiás kontroll továbbra is biztosított úgy, hogy az új terápia a beteg számára az életminőségben nem elhanyagolható jelentőségú javulással jár együtt.

Gesztációs diabetesben inzulinterápia válik szükségessé, ha a diétás előírások betartásával nem biztosíthatók az 
elöírt vércukorértékek. Várandósság alatt, a terhesség felismerésekor, vagy ideális esetben tervezett terhességkor már a pregesztációs gondozás keretén belül inzulinterápiára fordulunk korábban orális antidiabetikummal kezelt, ismert módon 2-es típusú diabetesben szenvedő cukorbeteg nők esetében. Az inzulinterápia igazodik az aktuális helyzethez, a várandósság előrehaladtával naponta többszöri gyors hatású inzulin adása is szükségessé válhat. Szülést követően rögtön újra kell értékelni az inzulinterápiát, a dózisokat csökkenteni kell, gyakran a teljes inzulinkezelés elhagyható. Ilyen esetekben a terápiás deeszkaláció szükségszerü lépés, annak módja és mértéke azonban mindig egyénileg állapítandó meg [37].

Végezetül az összetett inzulinkezelés egyszerúsítésével kapcsolatban még egy körülményre érdemes figyelmet fordítani. A 2-es típusú diabetesben szenvedők nagyobb mütétekor vagy súlyosabb interkurrens betegségekor az antihyperglykaemiás kezelés - igazodva a helyzethez általában napi négyszeri humán gyors hatású inzulin átmeneti adásával valósul meg. Ezt a terápiás rezsimet mútét után vagy infekció gyógyulásakor otthonra semmiképpen nem helyes a betegek számára javasolni. Diabetológus bevonásával meg kell találni azt a legegyszerübb antihyperglykaemiás kezelési rendszert, amely az adott beteg számára könnyen kivitelezhető, és várhatóan megfelelö glykaemiás kontrollt is biztosít a későbbiekben.

\section{A renalis funkció romlásakor}

A 2-es típusú diabetesben szenvedők között meglehetősen gyakori az idült vesebetegség egyidejü előfordulása, ami egyrészt a diabetes microangiopathiás szövődményeként, másrészt más betegségek (hypertonia, nephrosclerosis, pyelonephritis) társulása folytán jelenhet meg [38]. Jól ismert, hogy élettani körülmények között az eGFR értéke az életkor előrehaladtával fokozatosan csökken, a funkciókárosodás azonban kifejezettebb akkor, ha az érintett egyén cukorbeteg, és a diabeteshez vesebetegség is társul. Következésképpen egy adott cukorbetegnél az évekre elnyúló gondozás során számíthatunk arra, hogy egy korábbi, összetettebb kezelési forma fenntartását az adott eGFR-értékhez igazítani vagy az egész kezelési rendszert módosítani szükséges.

$\mathrm{Az}$ antidiabetikumok választásakor mindig figyelemmel kell lenni az alkalmazási elö́rásra, amely rögzíti, hogy az adott készítményt milyen eGFR-érték esetén lehet elkezdeni, illetve folytatni. Kevés kivétel van. Elvileg idetartozik az inzulin, de a gyakorlatban mégis tudni kell arról, hogy a renalis funkció beszúküulésekor az inzulindózisokat csökkenteni szükséges (olykor az inzulin akár el is hagyható), ha a hypoglykaemia kockázatát minimalizálni akarjuk. Az orális szerek között a DPP4-gátló linagliptin esetében nincs indok dózismódosításra alacsony eGFR esetén sem. A választani kívánt antidiabetikumok esetében mindig tájékozódni kell, hogy azok miként alkalmazhatók beszúkült vesefunkció esetén. Jellemző, hogy új klinikai tanulmányok nyomán a kontraindikációt jelentő eGFR-határérték módosul (alacsonyabb lesz), amint ezt megfigyelhettük az elmúlt évek során metformin, illetve több új, innovatív készítmény (például liraglutid) esetében is.

\section{Elörehaladó életkor, komorbiditások megjelenése esetén}

A 2-es típusú diabetesben elérendő glykaemiás célérték $\left(\mathrm{HbA}_{\mathrm{lc}}<7,0 \%\right)$ helyett az elmúlt években a glykaemiás céltartomány fogalma és az egyénre szabott kezelés szükségességének hangsúlyozása került előtérbe. Magas életkorban, társbetegségek jelenléte esetén a glykaemiás kontroll célja szerény (olykor 8,0-8,5\%-os $\mathrm{HbA}_{1 \mathrm{c}}$-érték is elfogadható), miután a kezelés intenzifikálása több gondot, mint előnyt jelent [26]. Egy váratlan hypoglykaemiás eseménynek beláthatatlan következményei lehetnek [39-43], a kicsit magasabb vércukorértékekkel összefüggő idült szövődmények kialakulási valószínüsége ugyanakkor elhanyagolható. Nem véletlenül fogalmaznak úgy egyes szerzők, hogy ilyen esetekben a kevesebb (antidiabetikum) többet jelent [44, 45]. Ebból adódik, hogy ebben a betegcsoportban gyakran sor kerülhet a korábbi összetettebb antihyperglykaemiás kezelés leépítésére, deeszkalációjára és a hypoglykaemia kockázatát nem növelő készítmények alkalmazására.

\section{A beteg szociális helyzetének romlásakor}

Az új, innovatív antidiabetikumok egységes 70\%-os társadalombiztosítási támogatásban részesülnek, megadott feltételek teljesülése esetén. A humán inzulinnal folytatott kezelés 100\%-os támogatást élvez, az inzulinanalógokkal folytatott huzamos kezelés 100\%-os támogatása $\mathrm{HbA}_{1 \mathrm{c}}$-értékhez kötött, 2-es típusú diabetesben szenvedők körében. A legkisebb anyagi terhet a betegeknek a nominatív támogatásban részesülő metformin- és szulfonilurea-készítmények jelentik. A kezelés költsége azonban gondot okozhat, ha a beteg szociális helyzete - bármely okból eredően - nem jó, vagy az az idő során romlik. Mindenki gyakorlatában előfordul olyan beteg, aki anyagi okokból eredően kéri a korábban egyébként bevált, szakmailag indokolt, de financiálisan megterhelőbb terápiás rezsim egyszerüsítését. Ilyenkor kényszerű okokból eredően a terápiában vissza kell lépnünk, az orális szerek közül metformin és/vagy szulfonilurea, illetve humán inzulin alkalmazása jön szóba. Egyébként az ADA-EASD legutóbbi (2018) konszenzusriportja és a hazai szakmai irányelv (2017) is nevesíti ezeket a készítményeket, amelyek előtérbe kerülnek akkor, ha a beteg számára a kezelés költsége komoly gondot jelent [8, 26]. 


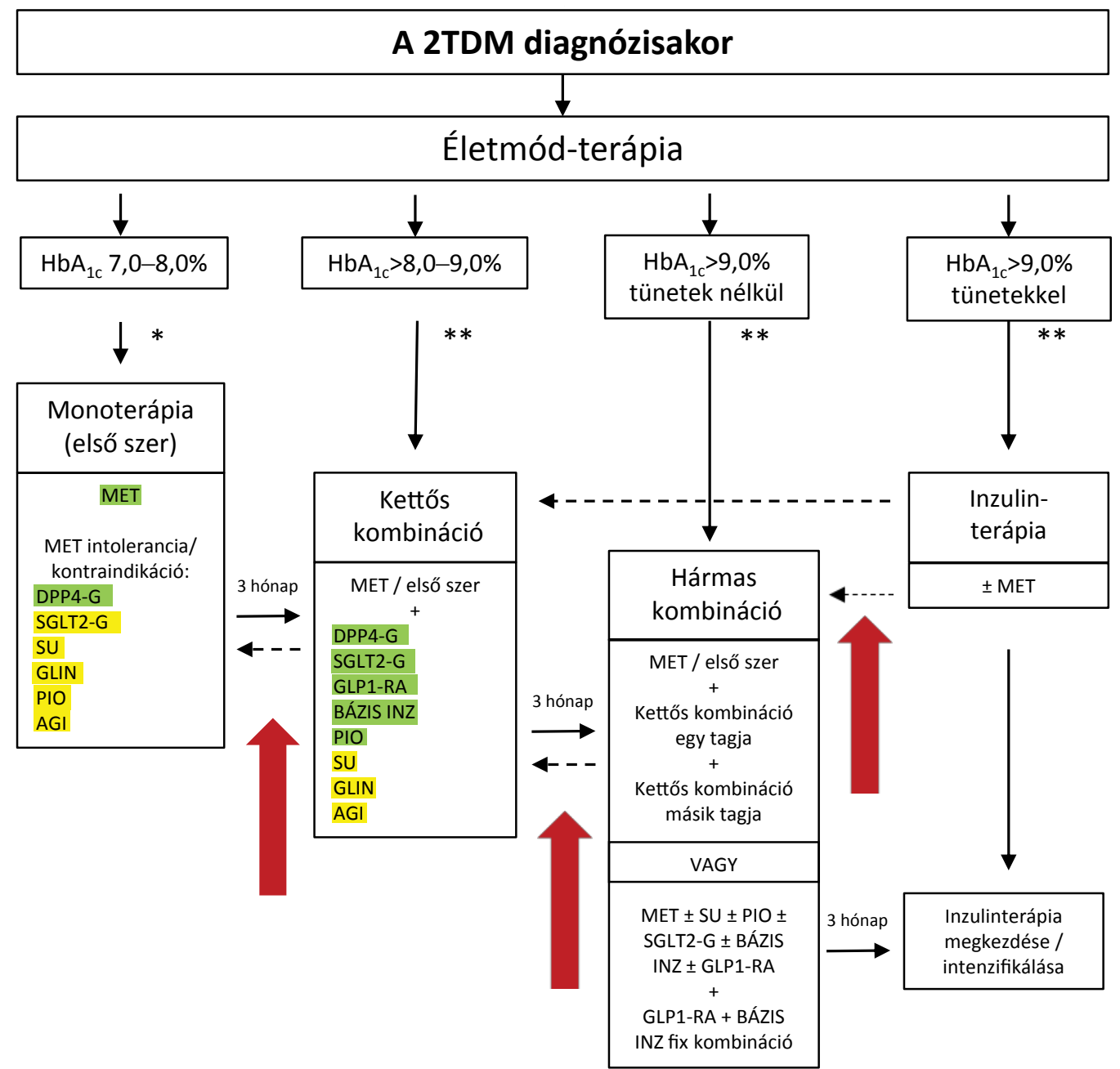

1. ábra

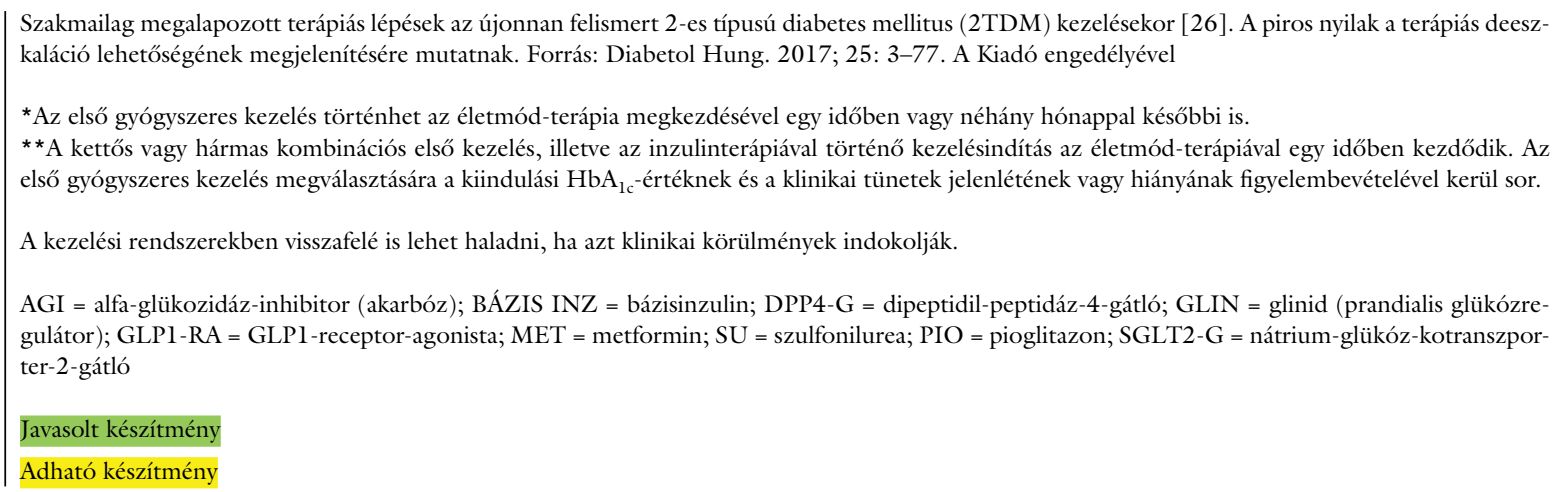

\section{A terápiás deeszkaláció megjelenítése szakmai irányelvekben}

A fentiekból látható, hogy a 2-es típusú diabetes antihyperglykaemiás kezelése során a terápia intenzifikálása mellett olykor a deeszkaláció lehetőségével is élnünk kell. Érdekes, hogy ez utóbbit a nemzetközi szakmai irányelvek, állásfoglalások, konszenzusnyilatkozatok algoritmusábrái nem tüntetik fel, csak egyirányú, előre mutató nyilak találhatók, amelyek a terápia bóvítésének, a lépcsőzetes kombinálásnak szükségességét jelzik [5-8].
A hazai szakmai irányelv legutóbbi, 2017-ben megjelent változatában [26] azonban a terápiás választásoknál a nyilak kétirányúak, azaz az előrelépés szükségességét jelző nyilak mellett megjelentek a visszalépés lehetőségét szemléltető, ellenirányú nyilak is az algoritmusábrákon (1. ábra). Ez talán azért is helyes, mert így kerül az algoritmusábra összhangba a glükózanyagcsere rendellenességeit (típusokat és stádiumokat) feltüntető alapvető ábrával (2. ábra). Jól látható, hogy a 2-es típusú diabetes stádiumaival összefüggésben változik a terápia - az anyagcsere-rendellenesség romolhat, stagnálhat vagy ja- 


\begin{tabular}{|c|c|c|c|c|c|}
\hline \multirow[t]{3}{*}{ Stádiumok } & \multirow{3}{*}{$\frac{\text { Normoglykaemia }}{\text { Normális glükózreguláció }}$} & \multicolumn{4}{|c|}{ Hyperglykaemia } \\
\hline & & \multirow{2}{*}{$\begin{array}{l}\text { Csökkent glükóztolerancia } \\
\text { vagy emelkedett éhomi } \\
\text { vércukor (prediabetes) }\end{array}$} & \multicolumn{3}{|c|}{ Diabetes mellitus } \\
\hline & & & $\begin{array}{c}\text { Inzulint } \\
\text { nem igénylő }\end{array}$ & $\begin{array}{c}\text { Inzulin szükséges } \\
\text { az anyagcsere- } \\
\text { kontrollhoz }\end{array}$ & $\begin{array}{c}\text { Inzulin szükséges } \\
\text { a túléléshez }\end{array}$ \\
\hline \multirow{3}{*}{\multicolumn{6}{|c|}{$\begin{array}{l}\text { 1-es típus* } \\
\text { 2-es típus } \\
\text { Egyéb speciális ípusok** }\end{array}$}} \\
\hline & & & & & \\
\hline & & & & & \\
\hline Gesztációs diabetes** & & & & & \\
\hline
\end{tabular}

2. ábra $\quad$ A glükózanyagcsere rendellenességei - típusok és stádiumok [46]. (Forrás: American Diabetes Association: Diabetes Care 2011; 34(Suppl 1): S62S69)

*Előfordul, hogy ketoacidosis tünetei után rövid időn belül normoglykaemia detektálható, s antidiabetikus gyógyszeres kezelés nem szükséges („honeymoon" periódus);

**Ritkán előfordul, hogy idetartozó betegek esetében a túléléshez inzulin adása válik szükségessé (pl. Vacor-mérgezés, l-es típusú diabetes kialakulása terhesség alatt).

vulhat, amivel összefüggésben a terápia bővülhet, változatlan maradhat vagy egyszerüsödhet [46]. Összefoglalva: a 2-es típusú diabetes antihyperglykaemiás kezelése során a terápia intenzifikálása mellett (ami nyilvánvalóan a betegek döntó többségét érinti) helye lehet adott esetben (a kevesebb beteget érintő) terápiás deeszkalációnak is. A klinikus a terápia megválasztásakor mérlegelést követően dönt; nem szabad megfeledkeznünk arról, hogy néha a kevesebb több.

Anyagi támogatás: A közlemény megírása anyagi támogatásban nem részesült.

A szerző a cikk végleges változatát elolvasta és jóváhagyta.

Érdekeltségek: A szerzőnek nincsenek érdekeltségei.

\section{Irodalom}

[1] U.K. Prospective Diabetes Study Group. Overview of 6 years' therapy of type II diabetes: a progressive disease. Diabetes 1995; 44: 1249-1258

[2] Turner R, Stratton I, Horton V, et al. UKPDS 25: autoantibodies to islet-cell cytoplasm and glutamic acid decarboxylase for prediction of insulin requirement in type 2 diabetes. UK Prospective Diabetes Study Group. Lancet 1997; 350: 1288-1293. Erratum in Lancet 1998; 351: 376

[3] Marselli L, Suleiman M, Masini M, et al. Are we overestimating the loss of beta cells in type 2 diabetes? Diabetologia 2014; 57 : 362-365.

[4] Ahlqvist E, Storm P, Käräjämäki A, et al. Novel subgroups of adult-onset diabetes and their association with outcomes: a datadriven cluster analysis of six variables. Lancet Diabetes Endocrinol. 2018; 6: 361-369.

[5] Garber AJ, Abrahamson MJ, Barzilay JI, et al. Consensus statement by the American Association of Clinical Endocrinologists and American College of Endocrinology on the comprehensive type 2 diabetes management algorithm - 2017 executive summary. Endocr Pract. 2017; 23: 207-238.

[6] Garber AJ, Abrahamson MJ, Barzilay JI, et al. Consensus statement by the American Association of Clinical Endocrinologists and American College of Endocrinology on the comprehensive type 2 diabetes management algorithm - 2018 executive summary. Endocr Pract. 2018; 24: 91-120.

[7] Inzucchi SE, Bergenstal RM, Buse JB, et al. Management of hyperglycemia in type 2 diabetes, 2015: a patient-centered approach. Update to a position statement of the American Diabetes Association and the European Association for the Study of Diabetes. Diabetes Care 2015; 38: 140-149.

[8] Davies MJ, D'Alessio DA, Fradkin J, et al. Management of hyperglycaemia in type 2 diabetes, 2018. A consensus report by the American Diabetes Association (ADA) and the European Association for the Study of Diabetes (EASD). Diabetes Care 2018; 41: 2669-2701.

[9] Dieci MV, Vernaci G, Guarneri V. Escalation and de-escalation in HER2 positive early breast cancer. Curr Opin Oncol. 2019; 31: $35-42$.

[10] Sibbing D, Aradi D, Jacobshagen C, et al. Guided de-escalation of antiplatelet treatment in patients with acute coronary syndrome undergoing percutaneous coronary intervention (TROPICAL-ACS): a randomised, open-label, multicentre trial. Lancet 2017; 390: 1747-1757.

[11] Chapman KR, Hurst JR, Frent SM, et al. Long-term triple therapy de-escalation to indacaterol/glycopyrronium in patients with chronic obstructive pulmonary disease (SUNSET). A randomized, double-blind, triple-dummy clinical trial. Am J Respir Crit Care Med. 2018; 198: 329-339.

[12] Frias Gomes C, Colombel JF, Torres J. De-escalation of therapy in inflammatory bowel disease. Curr Gastroenterol Rep. 2018; 20: 35. doi: 10.1007/s11894-018-0643-8.

[13] Seddon MM, Bookstaver PB, Justo JA, et al. Role of early deescalation of antimicrobial therapy on risk of Clostridioides diffcile infection following Enterobacteriaceae bloodstream infections. Clin Infect Dis. 2018 Oct 12. doi:10.1093/cid/ciy863. [Epub ahead of print]

[14] Vouri SM, Chen J, Sparkman J, et al. Antidiabetic medication de-escalation following bariatric surgery. J Diabetes 2018; 10 : 768-770.

[15] Winkler G. Metabolic effects of bariatric surgery. [A súlyleadás sebészetének (bariátriai sebészet) anyagcsere-vonatkozásai.] Orv Hetil. 2013; 154: 3-9. [Hungarian]

[16] Bene L. Invasive methods in the treatment of obesity. [Invazív módszerek az elhízás kezelésében.] Orv Hetil. 2016; 157: 728732. [Hungarian]

[17] Vasas P, Pór F. Current surgical options for reducing body weight. [A testsúlycsökkentés sebészeti lehetőségei.] Orv Hetil. 2014; 155: 971-977. [Hungarian] 
[18] Tisljár-Szabó E, Tisljár R. Psychological assessment of candidates for bariatric surgery. [Bariátriai mútétekre való pszichológiai alkalmasság felmérése.] Orv Hetil. 2019; 160: 448-455. [Hungarian]

[19] Schneider BE, Mun EC. Surgical management of morbid obesity. Diabetes Care 2005; 28: 475-480.

[20] Folli F, Pontiroli AE, Schwesinger WH. Metabolic aspects of bariatric surgery. Med Clin North Am. 2007; 91: 393-414.

[21] Carlsson LM, Peltonen M, Ahlin S, et al. Bariatric surgery and prevention of type 2 diabetes in Swedish obese subjects. N Engl J Med. 2012; 367: 695-704.

[22] Bradley D, Magkos F, Klein S. Effects of bariatric surgery on glucose homeostasis and type 2 diabetes. Gastroenterology 2012; 143: 897-912.

[23] Mingrone G, Panunzi S, De Gaetano A, et al. Bariatric surgery versus conventional medical therapy for type 2 diabetes. N Engl J Med. 2012; 366: 1577-1585.

[24] Coleman KJ, Haneuse S, Johnson E, et al. Long-term microvascular disease outcomes in patients with type 2 diabetes after bariatric surgery: evidence for the legacy effect of surgery. Diabetes Care 2016; 39: 1400-1407.

[25] Mingrone G, Panunzi S, De Gaetano A, et al. Bariatric-metabolic surgery versus conventional medical treatment in obese patients with type 2 diabetes: 5 year follow-up of an open-label, single-centre, randomised controlled trial. Lancet 2015; 386: 964-973.

[26] Jermendy G. (ed.) Clinical practice guideline - Diagnosis, antihyperglycaemic treatment and care of patients with diabetes in adulthood. [Egészségügyi szakmai irányelv - A diabetes mellitus kórismézéséről, a cukorbetegek antihyperglykaemiás kezeléséről és gondozásáról felnőttkorban.] Diabetol Hung. 2017; 25: 3-77. [Hungarian]

[27] Souteiro P, Belo S, Magalhães D, et al., Multidisciplinary Group for Surgical Management of Obesity. Long-term diabetes outcomes after bariatric surgery-managing medication withdrawal. Int J Obes (Lond). 2019 Jan 29. doi: 10.1038/s41366-0190320-5. [Epub ahead of print]

[28] Lean ME, Leslie WS, Barnes AC, et al. Primary care-led weight management for remission of type 2 diabetes (DiRECT): an open-label, cluster-randomised trial. Lancet 2018; 391: 541551.

[29] Lean ME, Leslie WS, Barnes AC, et al. Durability of a primary care-led weight-management intervention for remission of type 2 diabetes: 2-year results of the DiRECT open-label, clusterrandomised trial. Lancet Diabetes Endocrinol. 2019; 7: 344355.

[30] Davies MJ, Bergenstal R, Bode B, et al. Efficacy of liraglutide for weight loss among patients with type 2 diabetes: the SCALE diabetes randomized clinical trial. JAMA 2015; 314: 687-699.

[31] Hidvégi T. Effective and safe therapy for obesity: naltrexone/ bupropion combination. [Hatékony és biztonságos terápia az elhízás gyógyszeres kezelésében: a naltrexon/bupropion kombináció.] Diabetol Hung. 2017; 25: 393-399. [Hungarian]

[32] Hollander P, Gupta AK, Plodkowski R, et al., COR-Diabetes Study Group. Effects of naltrexone sustained-release/bupropion sustained-release combination therapy on body weight and glycemic parameters in overweight and obese patients with type 2 diabetes. Diabetes Care 2013; 36: 4022-4029.

[33] Torgerson JS, Hauptman J, Boldrin MN, et al. XENical in the prevention of diabetes in obese subjects (XENDOS) study: a randomized study of orlistat as an adjunct to lifestyle changes for the prevention of type 2 diabetes in obese patients. Diabetes Care 2004; 27: 155-161.

[34] Munshi MN, Hayes M, Sternthal A, et al. Use of serum C-peptide level to simplify diabetes treatment regimens in older adults. Am J Med. 2009; 122: 395-397.

[35] Pánczél P, Lukács K, Hosszúfalusi N. Classification of diabetes mellitus in the common clinical practice: the first step in precision diabetology. [Diabetestipizálás a mindennapi gyakorlatban: a precíziós diabetológia első lépései.] Diabetol Hung. 2017; 25 : 339-346. [Hungarian]

[36] Taybani Z, Bótyik B, Katkó M. Simplification of complex insulin regimens with preserving good glycaemic control in type 2 diabetes (abstract). Diabetologia 2018; 61 (Suppl 1): S414.

[37] Baranyi É, Winkler G. Diabetes and pregnancy. [Diabetes és terhesség.] Orv Hetil. 2011; 152: 1635-1640. [Hungarian]

[38] Tuttle KR, Bakris GL, Bilous RW, et al. Diabetic kidney disease: a report from an ADA consensus conference. Diabetes Care 2014; 37: 2864-2883.

[39] Abdelhafiz AH, Rodríguez-Mañas L, Morley JE, et al. Hypoglycemia in older people - a less well recognized risk factor for frailty. Aging Dis. 2015; 6: 156-167.

[40] Munshi MN, Slyne C, Segal AR, et al. Simplification of insulin regimen in older adults and risk of hypoglycemia. JAMA Intern Med. 2016; 176: 1023-1025.

[41] Maciejewski ML, Mi X, Sussman J, et al. Overtreatment and deintensification of diabetic therapy among medicare beneficiaries. J Gen Intern Med. 2018; 33: 34-41.

[42] Abdelhafiz AH, Sinclair AJ. Deintensification of hypoglycaemic medications - use of a systematic review approach to highlight safety concerns in older people with type 2 diabetes. J Diabetes Complications 2018; 32: 444-450.

[43] Hart HE, Rutten GE, Bontje KN, et al. Overtreatment of older patients with type 2 diabetes mellitus in primary care. Diabetes Obes Metab. 2018; 20: 1066-1069.

[44] McCoy RG, Lipska KJ, Yao X, et al. Intensive treatment and severe hypoglycemia among adults with type 2 diabetes. JAMA Intern Med. 2016; 176: 969-978.

[45] Lipska KJ, Ross JS, Miao Y, et al. Potential overtreatment of diabetes mellitus in older adults with tight glycemic control. JAMA Intern Med. 2015; 175: 356-362.

[46] American Diabetes Assocation. Diagnosis and classification of diabetes mellitus. Diabetes Care 2011; 34(Suppl 1): S62-S69.

(Jermendy György dr., Budapest, Maglódi út 89-91., 1106 e-mail: gyjermendy@gmail.com) 